\title{
A comprehensive educational system?
}

\section{¿Un sistema educativo comprensivo?}

\author{
Hinojosa, R.; Pinel, C.; Sáez, Laura. Universidad de Granada
}

Artículo dirigido por: Katia Caballero. Departamento de Didáctica y Organización Escolar. Universidad de Granada

Fecha de recepción: 31 de enero de 2014.

Fecha de revisión: 19 de marzo de 2014.

Fecha de aceptación: 11 de abril de 2014.

\begin{abstract}
Any good educational system tries to keep the maximum number of students in the educational system for as long as possible, where he or she will receive a quality education which will prepare him or her for higher education and the labour market. In other words, they fight for a comprehensive educational system. The LOMCE is going to achieve the complete opposite. We shall analyze this more deeply in the following paragraphs.
\end{abstract}

Keywords: Vocational training, higher vocational training, educational method, scholar evaluation, exam, income test, scholar dropout, basic education, secondary education, postsecondary education, higher education, private school, public school.

\section{Resumen}

Ningún sistema educativo intenta mantener el máximo número de estudiantes en el sistema educativo durante el mayor tiempo posible, donde el o ella recibirá una educación de calidad la cual los preparará para la educación superior y el mercado laboral. En otras palabras, ellos luchan por un sistema educativo comprensivo. La LOMCE va a lograr todo lo contrario. Nosotros analizaremos esto más profundamente en los siguientes párrafos.

Palabras clave: Formación profesional, formación profesional superior, método educativo, evaluación escolar, examen, examen ingreso, fracaso escolar, educación básica, enseñanza secundaria, educación postsecundaria, educación superior, colegio privado, colegio público.

\section{Introducción}

The LOMCE arrives with a new system to evaluate students' competences and performance in an external and national way. In this way, a new exam at the end of mandatory secondary education would be necessary to enter higher secondary education and also the level of exams to pass from higher secondary to university would change (LOMCE, Ley Orgánica 8/2013, de 9 de diciembre, para la mejora de la calidad educativa). This creates a system of segregation where school dropout is promoted. 
All of this implies an increase in the difficulty and quantity of exams students have to face throughout their stay in the educational system. Thus, teachers will orient their courses toward the external exams which students must take instead of concentrating on really useful and meaningfull matters to them. This concern is also discussed in The Forum Aragon article, as they claim: "throughout the whole law we find words such as competitiveness, excellence, results, instead of words such as training, free, critical citizens or socialization. School is not a factory" (Escabosa, Pérez Serrano and Santaflorentina, 2013).

Also, having students attention focused constantly on exams will make them more and more competitive. This competitiveness shall also be extended to schools in general as their ranking on the list of quality schools will depend on the results their students obtain in these exams.

\section{Selection of different routs at the age of fifteen}

The reform of LOMCE intends to justify the separation of students in two different itineraries: the academic route or the vocational training route. This shall be done in third and fourth year of mandatory secondary education, when students are fifteen years of age because they allegedly have enough autonomy to know which is the best path for themselves. According to Foro de Sevilla (2013), these paths are nothing more than a way to separate the better prepared students, which will follow the academic route, from those not quite so good students, who will follow the vocational training route. Students who fall into the second category will carry with them the label of being worse students, less prepared. They will be less valued, having access to different jobs from those who continue along the academic route. This creates different social statuses.

At the age of fifteen, if a student is not prepared to continue to the fourth year of this Mandatory Education, he or she can be put in a Basic Vocational Training course, preparing the student for the labour market. If the student wishes to continue to Higher Secondary education, he or she must pass the final Mandatory Secondary Education exam; this is twice the work that students who stayed at Mandatory Education have to do. In that way at the age of fifteen, those students begin to find barriers to continue their education.

Another thing we have to take into account is that students with special needs can be affected due to their economic position or their family factors, increasing disadvantages of those students compared with others. Private schools can use public money to specialize in certain educational needs. This allows families who have a strong economic position to be able to access these schools and choose the school which is specialized in whichever learning need or needs their child has, while low - income families will be limited to attending their local school, which will possibly not have the resources, either human or material, to cover the child's learning needs. In this situation it is clear that these students will be at a higher risk of being excluded from the educational system when they reach the age of fifteen. (Jose Luis Bernal Agud and Juan Lorenzo Lacruz, 2013).

\section{Retaking of a course and dropping out of school}

According to the PISA report (2013), "more than 25\% of Spanish students confirm that they have retaken a course". By making a child retake a course has double economic repercussions (a child is one year longer in the educational system and join the labour 
force one year later) and a psychological one (the students' self-esteem and/or motivation can be influenced).

Retaking a course is one of the main causes of school dropout, as it is a double-edged sword. Making a student retake a course may make this student reflect upon the consequences of his or her behaviour during the first round, but it may also achieve the opposite effect.

We can find several causes of dropout in schools. One of those is the lack of know-how of teachers. So, we need more highly-qualified teachers to compensate this situation in order to decrease the school dropout.

Other reasons for Spanish students wanting to leave the educationa system are teachers constantly using the the direct methodology, long class hours and many hours of daily homework. And to add to all of this, there has been an increase in students per teacher. Less human and economic resources result in a greater chance of failure, especially for those from poorer socio-economic contexts. (Foro de sevilla, 2013)

\section{Conclusion:}

This new law tries to boost the Spanish educational system as other laws have been trying in the previous years, each one making reforms to create an equalitarian educational system to which everyone can have access. However, this law has reinforced a centralized system concentrated on students passing the course instead of learning or acquiring useful knowledge for the real life. This creates competency between students and schools to obtain the best position in the ranking and, associated to this, prestige. Moreover, this educational law intends to reward those schools which obtain the best marks with more funding; this means that those schools with the best students will get more funding. The conclusion is that this will favor private schools, since they can choose to students. In turn, it will favor those families who have a good economic situation.

Another thing we have to take into account is the diversification which is created between students, dividing between "good" and "bad", and giving them labels from the first moment and creating more barriers for "bad students" to delay their entrance to university. We also have to take into account these students with specific needs and with a low economical level, who will not be able to access a school which can attend these needs. All this will culminate in the increase of school dropout because they will not reach their goals because of these barriers or because the public schools teachers' low qualification, which will lead to frustration on their behalf.

In conclusion it would be wise to remember a quote from Confucius about how a good education affects to a society: Where there is a good education there is no class distinction.

\section{Bibliographical references}

BOLÍVAR BOTÍA, A. (2012a). Hastiados de reformas educativas. Revista ESCUELA. Retrieved 3rd June 2013. http://en-clase.ideal.es/index.php/opinion/1141-antonio-bolivar-Ihastiados-de-reformas-educativasr-.html

BOLIVAR BOTÍA, A. (2012b). Transformar el modelo educativo. Retrieved 3rd June 2013. http://www.blogcanaleducacion.es/transformar-el-modelo-educativo/ 
BOLIVAR BOTÍA, A. (2013). ¿Cómo incide la LOMCE en la organización de los centros? Forum Aragón, 7. Retrieved 3rd June 2013. http://www.feae.es/docs/20130312_forum\%20_aragon_7.pdf

BOLIVAR BOTÍA, A., SAN FABIÁN, J.L. (2013). La LOMCE, ¿una nueva ley para mejorar la calidad educativa? Organización y Gestión Educativa. Retrieved 3rd June 2013. http://www.oge.net/ver_pdf.asp?idArt=15963

COLL, C. (2012). Diez preguntas para el Ministro Wert. Retrieved 3rd June 2013. http://www.colectivolorenzoluzuriaga.com/PDF/Diez\%20preguntas\%20a\%20We rt.pdf

ESCABOSA CARABALLO, T.; PÉREZ SERRANO, J.C.; SANTAFLORENTINA EJARQUE, L. (2013). Dudas sobre la LOMCE. Forum Aragón, 7. Retrieved 3rd June 2013. http://www.feae.es/docs/20130312_forum\%20_aragon_7.pdf

ESCUDERO, J.M. (2002). La reforma de la reforma. ¿Qué calidad, para quiénes? Barcelona: Ariel. $\quad$ Retrieved Jrd June 2013. http://www.ugr.es/ recfpro/rev61re.pdf

ESCUDERO MUÑOZ, J.M. (2012). Reformas y cambios en la educación en tiempos difíciles. Retrieved 3rd June 2013. http://ademeblog.wordpress.com/

FERNÁNDEZ ENGUITA, M. (2012). ¿A dónde quiere devolvernos wert?.Retrieved 3rd June 2013. http://enguita.info/776/

SAN FABIÁN MAROTO, J.L. (2011). The Role of School Organization in Educational Change the Inertia of the Status Quo.Revista de Educación, 356. Retrieved 3rd June 2013. http://www.revistaeducacion.educacion.es/re356/re356_02.pdf

Ley Orgánica 8/2013, de 9 de diciembre, para la mejora de la calidad educativa, LOMCE.

Informe del Programa Internacional para la Evaluación de Estudiantes, PISA 2013.

BERNAL AGUD, J.L.; IACRUZ, J.L. (2013). La privatización de la educación pública. una tendencia en España. Un camino encubierto hacia la desigualdad. Retieved 3rd June 2013. http://www.ugr.es/ recfpro/rev163ART5.pdf 